\title{
Chapter 17 \\ Integrated Rice-Fish Farming System in Bangladesh: An Ex-ante Value Chain Evaluation Framework
}

\author{
Abu Hayat Md. Saiful Islam
}

\begin{abstract}
Rice and fish are an important source of food and nutrition security, income, and livelihood options for many people in Bangladesh. Integrated rice-fish farming systems are a potential option which respond to scarce land and water resources but their potential has not been fully explored in the country. Thus, this study assesses the ex-ante socio-economic competitive potential of this technology, as well as the crucial factors for its widespread adoption and diffusion. To assess the true performance of an activity, we take into account its upstream and downstream actors who are directly or indirectly related to that activity. The overall quantitative results from gross margin, partial budgeting and gendered employment analyses show positive benefits due to the introduction of rice-fish technology instead of rice monoculture in Bangladesh.
\end{abstract}

Keywords Integrated rice-fish farming system • Ex-ante assessment $\bullet$ Value chain evaluation framework $\bullet$ Partial budgeting $\bullet$ Bangladesh

\section{Introduction}

With more than 150 million inhabitants in an area of $147,570 \mathrm{~km}^{2}$, Bangladesh is characterized as one of the most densely populated countries in the world (about 964 persons $/ \mathrm{km}^{2}$, or only 0.06 ha available per head), with rapid population growth (1.37\% per annum) and low per capita income (\$848 (US) per year) (BER 2012; World Bank 2012). Although the poverty level declined in the last decade at an impressive rate, the absolute number of people below the poverty line remains significant. Around 53 million people still live below the poverty line and most of them (about $75 \%$ ) live in rural areas (World Bank 2012; BER 2012). Agriculture (including fisheries) is still one of the major contributors to the economy,

\footnotetext{
A.H. Md. Saiful Islam $(\bowtie)$

Center for Development Research, University of Bonn, Bonn, Germany

Department of Agricultural Economics, Bangladesh Agricultural University,

Bonn, Germany

e-mail: saiful_bau_econ@yahoo.com 
accounting for $20 \%$ of GDP and growing at $5 \%$ over the years. Most of the rural people directly or indirectly engage with agriculture for their daily livelihood and about $48 \%$ of labour is employed in this sector (BER 2012). From ancient times, agriculture, including fisheries, has been an integral part of the life of the Bangladeshi people, and plays a major role in food security, employment, nutrition, foreign exchange earnings and other aspects of the economy. Fish with rice is the national diet, giving rise to the proverb Maache-Bhate Bangali ("A Bengali is made of fish and rice"): fish alone supplies about $60 \%$ of animal protein intake and rice alone supplies $70 \%$ of direct human calorie intake (Alam and Thomson 2001; DOF 2010; Sarder 2007). Bangladesh is one of the top nations in terms of producing and consuming rice and fish, and both are associated with the daily food culture of the Bangladeshi people, especially for poor rural people.

Due to high population growth, economic development and urbanization demand for rice and fish is increasing day by day. On the other hand, the supply is threatened due to conversion of agricultural land, climate change and the environmental impact of overuse of fertilizer and pesticides during the green revolution period. Thus, there is an urgent need for a sustainable option which can produce rice and fish in a sustainable manner. Integrated rice-fish farming systems (IRFFS) seem to be such an option, producing more rice and fish with less use of land and water in a sustainable way. Since its inception, different researches have shown that it is ecologically/environmentally friendly, works as IPM, increases soil fertility, optimally uses scarce land and water resources complementarily, increases productivity, environmental sustainability, system biodiversity, intensification, farm diversification and household nutrition, and is a sustainable option for producing rice and fish through less use of land and water (Frei and Becker 2005; Fernando 1993; Nhan et al. 2007; Ahmed and Garnett 2011; Ahmed et al. 2011; Berg 2001, 2002; Halwart and Gupta 2004; Halwart et al. 1996; Little et al. 1996; Lightfoot et al. 1992; Giap et al. 2005; Rothuis et al. 1998a, b, 1999; Haque et al. 2010; Dugan et al. 2006; Coche 1967; Gurung and Wagle 2005). Although the potentiality of this technology has been widely documented, rice-fish farming systems are still not widespread in Bangladesh, remaining a marginal farming system (Ahmed and Garnett 2011; Ahmed et al. 2011; Nabi 2008). This issue gives major impetus to properly assessing the potential socio-economic benefit of this system compared to rice-monoculture, as well to identifying the factors which facilitate and hinder rice-fish technology adoption and diffusion.

For widespread diffusion of and proper policy-making in regard to integrated rice-fish farming systems, it is necessary to know the adoption pattern as well as its impacts (Noltze et al. 2012; Becerril and Abdulai 2010). Doss (2006) mentioned that, after 20 years, technology adoption studies have made substantial progress in examining the intensity of adoption (not just dichotomous choices) and addressing the simultaneity of adoption of different components of a technology package. However, the issues of how institutional and policy environments affect the adoption of new technologies and how the dynamic patterns of adoption affect the distribution of wealth and income remain unanswered. To the best of our knowledge, no studies have been done considering those aspects in the case of integrated rice-fish farming systems in Bangladesh, although value-chain analysis, along with 
such useful tools as partial budgeting and SWOT analysis, can work as an ex-ante framework for assessing the details of performance of this farming system by considering the upstream and downstream actors (like Macfadyen et al. 2012; Veliu et al. 2009; Christensen et al. 2011) compared to the rice-monoculture value chain. Value chain analysis is a strong qualitative as well as quantitative approach widely applied to pro-poor economic development. It can assess economic viability and sustainability and identify the critical issues and impasses for different actors, and then generate robust and effective policies and development strategies (Coles and Mitchell 2011). Thus, this study is an attempt to fill this research gap by using the powerful value chain analysis as a framework for assessing the comparative performance of integrated rice-fish farming systems for indigenous peoples in Bangladesh. The article's most important contribution is its use of the three above-mentioned forms of analysis to assess the performance of rice-fish technology in marginalized, extreme poverty settings, which, in turn, will help to design and execute pro-poor agricultural interventions to reduce extreme poverty and marginality in the developing world. To do so, the paper continues as follows: the next section presents the research methodology, including data and analytical research, employed in this paper. A result and discussions section comes next, including subsections regarding value chain mapping, gross margin analysis, partial budgeting and SWOT of the integrated rice-fish farming system value chain. The paper finishes with a discussion of the conclusions and policy implications of our findings.

\section{Methodology of the Study}

\section{Data and Study Area}

Data were collected between August 2012 and January 2013 at 12 Upazilas in the Dinajpur, Rangpur and Joypurhat Districts in the northwestern region and at 4 Upazilas in the Netrokona and Sherpur Districts in the northern region (Fig. 17.1). The study sites were chosen because there was an EU-funded adivashi fisheries project conducted by the WorldFish Center with its partner organizations from 2007 to 2009 . These farmers received training and other facilities in rice-fish farming, and other actors also received training and initial financial support from the Adivashi Fisheries Project, ${ }^{1}$ funded by the European Union. These districts were therefore selected for the study.

A field survey for collecting primary data was done by using two types of detailstructured interview, scheduled for a period of 6 months by the trained enumerators with the supervision of one of the primary authors of this paper. The interview schedule was prepared and finalized based on relevant literature reviews, pretesting and expert consultation. These two finalized interview schedules were used by a

\footnotetext{
${ }^{1}$ See Pant et al. (2014) for a detailed discussion about the Adivashi fisheries project.
} 


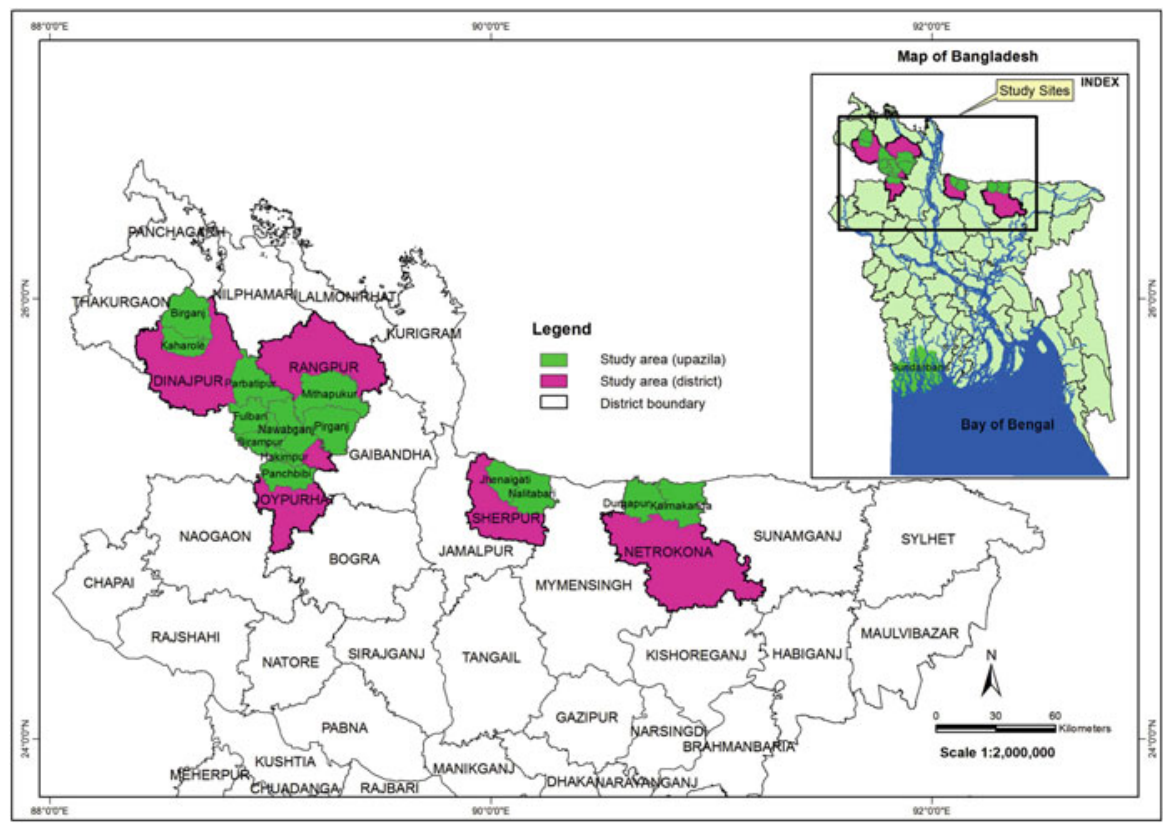

Fig. 17.1 Study areas: districts and sub-districts are indicated by purple and green, respectively (Islam et al. 2015)

trained enumerator in the field to conduct the surveys. Data were collected from integrated rice-fish farming system value chain participants. The details of the sample size used in this study are shown in Table 17.1. The author got the participant list from the WorldFish Center, and a sample was chosen randomly from that list. Farmers were interviewed at their houses and/or farm sites. After data was collected by the enumerator, the supervisor checked the data in the field and, if there was any indication of error or confusion, cross-validation was done by the supervisor with the same farmers. During the entire period of fieldwork, observation (direct observation, passive deception) by participants was used to triangulate the information gathered through interviews (Bernard 2006).

In addition to primary data, secondary data were collected whenever necessary from various government sources like the Department of Fisheries (DOF), the WorldFish Center (WFC) and other relevant ministries in Bangladesh, as well from review of the extensive published literature. 
Table 17.1 Sample size by category

\begin{tabular}{l|r|r}
\hline Category & Sample size & Percent \\
\hline Fingerling trader & 17 & 4.02 \\
\hline Rice-fish & 48 & 11.35 \\
\hline Rice-monoculture $^{\mathrm{a}}$ & 311 & 73.52 \\
\hline Fisherman & 19 & 4.49 \\
\hline Fish trader & 28 & 6.62 \\
\hline Total & 423 & 100.00 \\
\hline
\end{tabular}

${ }^{a}$ Within the rice-monoculture category, there are 132 samples from non-indigenous farmers, collected randomly from the neighboring indigenous households, with the rest of the ricemonoculture farmers and other categories coming solely from indigenous households

\section{Analytical Methods}

\section{Value Chain Analysis}

Since value chain analysis became widely used in the early 1990s as a novel methodological tool for understanding the dynamics of a system, there has been no hard and fast definition of the concept of the value chain. Definitions vary widely depending on the authors and their fields and scopes of study. Thus, it is necessary to clarify briefly how we define the term 'value chain' in this study. According to Kaplinsky and Morris (2001), a value chain "describes the full range of activities which are required to bring a product or service from conception, through the different phases of production (involving a combination of physical transformation and the input of various producer services), delivery to final consumers, and final disposal after use" (Kaplinsky and Morris 2001, p. 4; Kaplinsky 2000). Value chain analysis focuses on 'vertical', as well as 'horizontal', linkages among different actors and the movement of goods or services from producer to consumer along the chain. Value chain analysis is widely used throughout the whole industry, and more recently, in agricultural sector research and policy fields, as an analytical tool, even in environments of more complex production networks (Kaplinsky 2000; Dolan and Humphrey 2004; Gereffi 1994; Sturgeon 2001). Value chain analysis can analyse values and value addition within the chain, the nature of power relations and power distributions based on governance of the supply chain, and potential points of entry or exclusion (especially in the case of small farmers), as well as the distribution of revenues and benefits among the actors (Walters and Lancaster 2000; Doland and Humphery 2004; Wood 2001). In addition, value chain analysis allows us to integrate the gendered (e.g., Barrientos et al. 2003), nutrition (e.g., Fan and Pandya-Lorch 2012), welfare, poverty, inequality and environmental concerns (e.g., Bolwig et al. 2010; Kaplinsky 2000; Riisgaard et al. 2010; Gereffi et al. 2001; Trifković 2014).

Many methods of value chain approach have evolved over the years as it has been used in various disciplines, such as economics, environmentalism, political science, etc. (Fasse et al. 2009). Broadly, it can be categorised into two groups: one 
that is more descriptive and qualitative emphasized (Kaplinsky and Morris 2001), and another that refers to specialized tools with an analytical focus with is more quantitatively oriented, such as modelling and simulation, especially in business administration, e.g., optimizing chain logistics (Ondersteijn et al. 2006). The blending of qualitative and quantitative methods in value chain analysis can include a combination of surveys, focus group interviews, participatory rapid appraisals, informal interviews, and secondary data sourcing. It is also important to look at the institutions, their arrangement and how they are embedded in the chain to get to know the economic, social and political implications. This sort of analysis is especially affected by certain norms, working rules, and property relations, which have a big influence on the choice of the individual, meaning the particular internal or external stakeholder of the chain. Different actors decide whether they are willing to agree and act on the next step or not. Here, the term 'governance' comes into consideration. Because under these circumstances, 'governance' means the 'transformation' of institutions driven by the actors. With this regard, governance (systems) shows whether institutions become effective or not (Hagedorn 2008, p. 360). As goods and services move along the chain from actors to actors, every time a good or service is transferred between the actors (transaction), costs emerge, which might be fixed or variable. So, coordination problems arise. According to Williamson (1985), three determining factors of transaction exist: Asset specificity, uncertainty and frequency. Asset specificity is related to the specific investment for the transaction and how costly the investment is in comparison to an alternative use of the good/service. The more difficult it is to reallocate the resource to another use, the more specific the transaction. Uncertainty means the uncertain action or behaviour of the contract partner. Frequency indicates the repetition and number of transactions. The more frequent it is, the more trust exists between the actors, and the less probability there is of opportunistic behaviour.

Various types of analysis can be undertaken through the use of the value chain approach, such as functional analysis (Bahr et al. 2004; Guptill and Wilkins 2002), institutional analysis (FAO 2005a), social network analysis (Kim and Shin 2002), financial analysis (FAO 2005b), input-output analysis (Hecht 2007), social accounting matrix (Courtney et al. 2007; Adelman et al. 1988), life cycle analysis (Rebitzer et al. 2004), input-output-life cycle analysis (Lenzen 2001), material flow analysis (Finnveden and Moberg 2005), energy analysis (Finnveden and Moberg 2005) and an integrated ecological-economic modelling approach (Pacini et al. 2004; Baecke et al. 2002; Kledal 2006). One method could not hope to cover all relevant aspects, so in this study, we used a combination of methods: functional analysis, which depicts the interaction between actors of the value chain, describing their full activities from node to node along the chain; institutional and social network analysis, which presents an overview of the various chain actors the and relationships between people, groups and organizations in value creation; financial and input-output analysis, which determines the financial costs and benefits of the individual agents along the chain and traces the flow of goods and services between actors; and material flow analysis, which assesses the physical units of input and output involved in the production, processing, consumption and distribution. 


\section{Gross Margin Analysis}

Gross return (GR) is calculated by multiplying the total volume of output by the average price in the harvesting period (Dillon and Hardaker 1989). The following equation was used to estimate GR:

$$
\mathrm{GR}_{\mathrm{i}}=\sum_{i=1}^{n} \mathrm{Q}_{\mathrm{i}} \mathrm{P}_{\mathrm{i}}
$$

Where,

$\mathrm{GR}_{\mathrm{i}}=$ Gross return from the $\mathrm{i}^{\mathrm{th}}$ product $(\mathrm{Tk} / \mathrm{ha})$

$\mathrm{Q}_{\mathrm{i}}=$ Quantity of the $\mathrm{i}^{\mathrm{th}}$ product $(\mathrm{kg})$

$\mathrm{P}_{\mathrm{i}}=$ Average price of the $\mathrm{i}^{\text {th }}$ product $(\mathrm{Tk} / \mathrm{kg})$

$\mathrm{i}=1,2,3 \ldots \ldots \ldots \ldots \ldots \ldots \ldots, \mathrm{n}$

\section{Gross Margin}

In farming, the financial performance of an activity is usually expressed in terms of a gross margin, defined as the difference between gross return and total variable costs. Fixed costs are not included (Nix 2000).

That is,

$$
\mathrm{GM}=\mathrm{GR}-\mathrm{TVC}
$$

Where,

$\mathrm{GM}=$ Gross margin

$\mathrm{GR}=$ Gross return

$\mathrm{TVC}=$ Total variable cost.

\section{Benefit Cost Ratio (BCR)}

The BCR is a relative measure, which is used to compare benefit per unit of cost. The BCR was estimated as a ratio of gross returns and total variable costs. The formula for calculating BCR (undiscounted) is shown below:

$$
\text { Benefit cost ratio }=\frac{\text { Gross return }(\mathrm{GR})}{\text { Total variable cost }(\mathrm{TVC})} .
$$




\section{Partial Budget Analysis}

Partial budgeting is normally used to re-evaluate the economic viability when there is a minor change in a production technique resulting in a partial change in the costreturn structure (Shang 1986; Barnard and Nix 1979). Partial budget analysis assesses the incremental technological change at the field level (Holland 2007; Roth and Hyde 2002). It includes only those resources that will be changed, leaving out those that are unchanged (e.g., fixed assets), and supports the assessment of alternatives. Partial budget is a balance which measures the positive and negative effects of a change in the existing activities (Kay et al. 2008). It shows how adopting a new technology affects profitability by comparing the existing one with the new or alternative methods. It is based on the concept that technological change will have positive and/or negative economic effects. On the positive side, it is assumed that the adoption of technological innovation will eliminate or reduce some costs and/or will increase returns. On the negative side, it is assumed that technological change will cause some additional costs and/or reduce some returns. The net effect of the introduction of technological innovation is measured by the net change between positive and negative economic effects. A positive and negative net change indicates a potential increase and decrease in income/profit, respectively, due to the introduction of the new technology (William et al. 2012). In this article, we used partial budgeting technique to re-evaluate the economic viability of an integrated rice-fish farming system instead of a rice monoculture system.

\section{SWOT Analysis}

SWOT analysis as a framework is uncritically widely used due to its simplicity and practicality. SWOT (the acronym stands for Strengths, Weaknesses, Opportunities and Threats) analysis is used for analyzing internal and external factors in order to attain a systematic approach and support for decision-making. It is a valuable tool for addressing some of the weaknesses of quantitative analyses. The aim of this type of analysis is to try and maximize the future position of an organization/business/ enterprise/activity, in our case, a rice-fish farming system in Bangladesh (Kurttila et al. 2000).

SWOT analysis is a strategic planning tool consisting of two parts (FAO 2006):

1. An analysis of the internal situation (strength and weakness). This only discusses actual strengths and weaknesses rather than speculative, future strengths and weaknesses.

2. An analysis of the external situation (opportunities and threats). This includes the actual situation, i.e., existing threats, as well as unexploited opportunities and probable trends.

New technologies like the rice-fish system are promoted as having the potential to improve the economic, environmental, and health conditions in developing 
countries. However, the adoption rates of these new technologies are often disappointing and are not uniform (Feder et al. 1985). In this article, we use SWOT analysis to identify and analyze the constraints and facilitating factors for adoption and diffusion of integrated rice-fish farming system technology in Bangladesh, in general, and among the indigenous communities in particular.

\section{Results and Discussion}

\section{Value Chain Mapping}

Value chain analysis determines how the linkages between the production, distribution and consumption of products are interconnected along the value chains that represent a network of activities and actors (Kaplinsky 2000; Sturgeon 2001). The value chain approach identifies the input-output structure or the value-added sequence in the production and consumption of a product; dispersion of production and marketing; a governance structure or the power relations that determine how financial, material and human resources are distributed within the chain; and an institutional framework that identifies how local, national, and international contexts influence activities within chains (Gereffi 1994, 1995). Governance structures determine how the benefits of participation are distributed along the chain (Gereffi et al. 2001; Gibbon 2000; Humphrey and Schmitz 2001). Governance structures can be producer-driven and/or buyer-driven (Gereffi 1995). These structures are helpful for identifying how the power is exercised within chains (Barrientos et al. 2003).

The rice-fish value chain maps in Fig. 17.2 provide a schematic snapshot of the key value chain actors and the product and information flows at a given point in time. The horizontal product flows indicate the alternative supply channels, while each vertical level in the value chain describes the productive function. Value chains encompass a network of competing supply/marketing channels. The chain of actors through which the transaction of goods takes place between producer and consumer constitutes a marketing/supply channel. In other words, a marketing channel refers to a pathway composed of various marketing intermediaries who perform such functions as needed to ensure smooth and sequential flow of goods and services from the producers to consumers. Marketing/supply channels are alternative routes of product flows from producers to consumers (Kohls and Uhl 2002). In Bangladesh, fish produced in a rice-fish system moved from the producerintermediaries to consumers through the channel, i.e., through some market intermediary, such as fish wholesalers and retailers. It was observed that fish produced in a rice-fish system needed to move a short distance from the point of production to the consumers due to its perishable nature and small-scale production, as well as the high demand in the local market. Within the value chain, marketing channels through which the fish produced in a rice-fish system moved in Bangladesh are observed in the study areas, which are depicted in Fig. 17.2. Here, we only discuss 


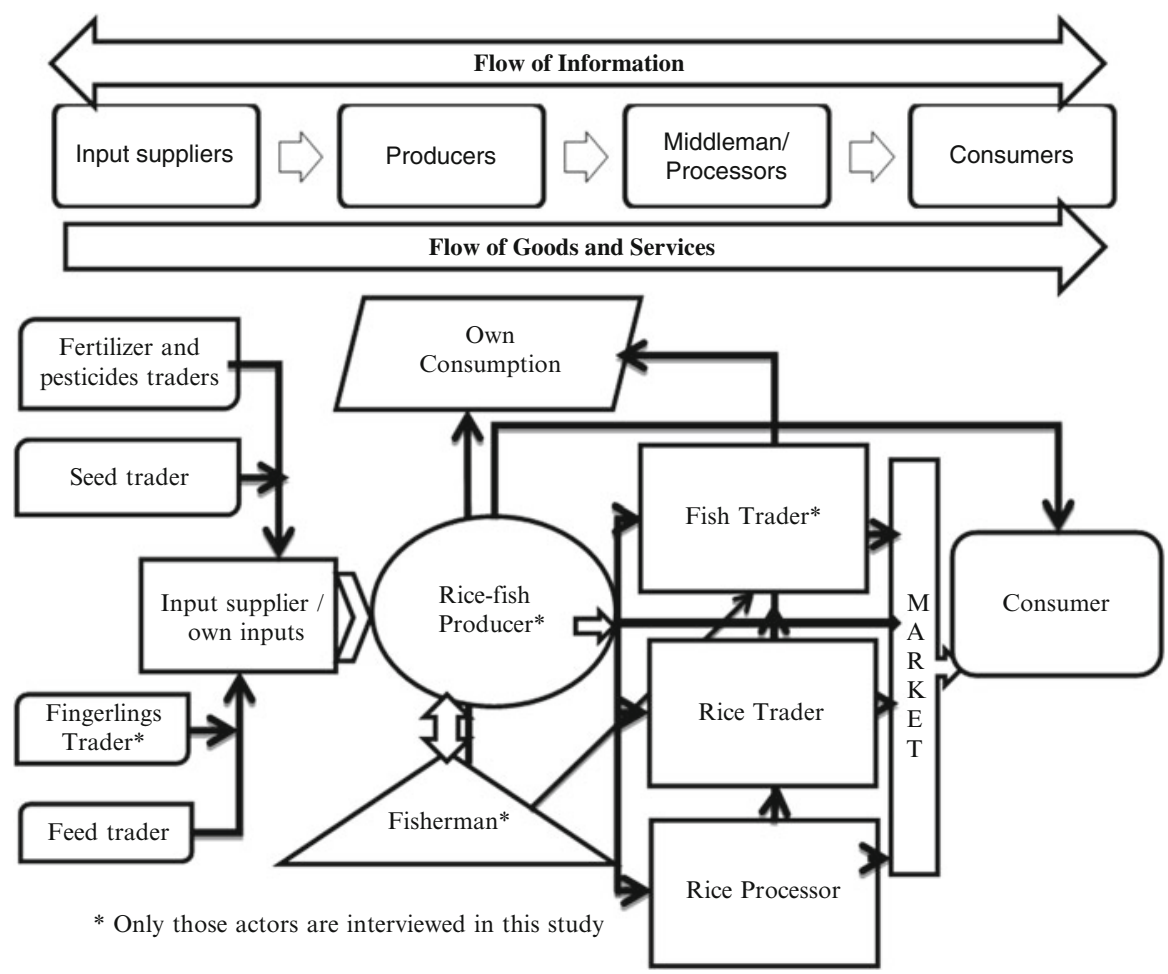

Fig. 17.2 Value chain of rice-fish technology in Bangladesh

the fish value chain under the rice-fish system value chain rather than both rice and fish, although both are shown in Fig. 17.2, because we assume that the fish value chain brought extra benefit to the rice value chain, the actors of which are working within a rice-fish system rather than rice monoculture. For a detailed value chain analysis of rice, please see Minten et al. 2011, 2013; Reardon et al. 2012.

In Fig. 17.2, we observe only a few channels that are used for rice-fish production and distribution, channels that are very short. Rice-fish farmers produced rice and fish by using their own inputs or buying them from input suppliers like fingerling traders; they also use the services of fisherman. Fish produced under a rice-fish system are consumed by the rice-fish producing households fully or partly, with the rest being sold to neighbouring households or in the nearby market; alternatively, they may sell it to a fish trader, who then sells it to the consumers through a market and possibly consumes some portion of it themselves. In these channels, major actors of fish production and distribution under a rice-fish system are fingerling traders, rice-fish small-scale farmers, fisherman, fish traders and consumers, the latter group of which may itself contain fingerling traders, ricefish small-scale farmers, fisherman, and fish traders, all of whom were interviewed in this study. 
All these actors play an important role along the chain. The input suppliers supply input, mainly fish fingerlings, to the small-scale rice-fish farmers through credit or cash. In our case, the farmers said they only bought the fingerling from fingerling traders, and mostly used feed they made themselves at home or sometimes that which they would buy from the nearby feed traders/market. The fish traders collect the fish from farms using their own transportation to take them to the nearby market, or sometimes buy and sell the fish in the same market. From the value chain map in Fig. 17.2, it is evident that rice-fish producers have several options for making good use of their fish, whether it's through their own consumption, or directly selling it to the market, neighbouring consumers or fish traders, and similarly, consumers also have the opportunity to buy from different sources.

\section{Actors, Value Addition, Governance, Institutional Framework and Gendered Employment in the Value Chain}

Major actors in the rice-fish value chain are input suppliers (fertilizer and pesticide traders, seed traders, feed traders and fingerling traders), rice-fish producers, fisherman, rice and fish traders, rice processor/millers and consumers. Normally, many functions/services are offered by different actors along the chain, such as exchange functions (buying and selling), physical functions (transport, storage, processing) and facilitating functions (standardization, financing, risk-bearing and market intelligence) (Kohls and Uhl 2002). As we have observed, the fish value chain under a rice-fish system is neither that long nor that simple. Almost all farmed and wild fish are sold either live, fresh on ice, or fresh without ice; there is no primary or secondary processing at all. For producing fish in the rice field, farmers who do not use much feed primarily rely on natural food (phytoplankton, zooplankton, periphyton and benthos). Some farmers use additional supplementary feed that they often make themselves at home (like cow-dung, waste rice, rice and wheat bran, etc.). In addition, some farmers, especially those on relatively large farms, sometimes buy feed (like mastered oilcake, poultry manure, fishmeal, industrially manufactured pelleted feeds etc.) from the feed traders in the nearby market. Major species cultivated under a rice-fish system tend to be major Indian carp species, both prevalent and exotic, like common carp (Cyprinus carpio), catla (Katla katla), rohu (Labeo rohita), mrigal (Cirrhinus mrigala), bata (Labeo bata), Nile tilapia (Oreochromis niloticus), silver carp (Barbodes gonionotus) and naturally occurring small indigenous species (SIS). Normally, all rice-fish farmers use a slightly larger size of fingerling in a rice-fish system, believing that fingerlings who start out a bit bigger will grow faster than those that start out smaller. In general, under a rice-fish farming system in Bangladesh, farmers will not stock any specific ratio of different fish species (Ahmed and Garnett 2011). Almost all the actors participating in the production and distribution channel consumed fish throughout the production and distribution period. Fish are harvested by fisherman, and 
sometimes by the farmers themselves, then sold to neighbors, or the wholesalers and retailers in the nearby market. Farmers sometimes grade by species or by size of the fish to get higher and differentiated prices. Most of the time, naturally occurring SIS of fish by-pass the established market and are both sold to neighbors and consumed by the farmers themselves, due to good testing and greater demand for smaller and cheaper fish, as the purchasing power of the local population is weaker. Different studies show that SIS of fish are very nutritious and have the potential to ensure food and nutrition security in the developing world (Roos et al. 2003, 2007a, b; Thilsted et al. 1997). Fish traders (wholesalers or retailers) either collect fish from the farmers or have the farmers deliver the fish to them, and then sell it to retailers, consumers, and restaurant owners.

Once fish have been harvested from a rice-fish farm, there are no distinct valuechains for different species, i.e., individual traders/wholesalers and retailers deal in all fish species, rather than in particular ones. All rice-fish farmers reported that they produce and sell a mix of fish species, dominated by sales of carp, but also including tilapia and SIS. Almost all fish is sold live, with some being sold fresh on ice (in the summer months or if sales are conducted relatively far from the harvest area). There is a growing trend in the country's consumers for live and fresh fish and a preference for wild fish over farmed fish. Thus, a rice-fish system is a potential technology for fulfilling those demands in Bangladesh and other developing countries. In the rice-fish value chain, we see the fish distributed through a few short channels and very few actors involved in the performance of different marketing functions, such as buying, selling, transportation, processing/grading, cooling/ icing, pricing, etc., adding value to the product by working those functions and taking a portion of the marketing margin (discussed in the next section) as a result; the reason there are so few value addition functions is that the fresh fish are typically being harvested and sold on the same day. Fish produced under a ricefish system value chain are governed by the spot market transactions involving a large number of small traders, which is the case in many traditional agricultural commodity value chains in developing countries, while the modern value chains' governance is based on the use of high standards and safety throughout the chains, high levels of vertical coordination (such as contract-farming), a high degree of coordination of the supply base, and agro-industrial processing (Maertens and Swinnen 2010). Power relations among the actors are almost balanced/equal because all the actors' operation units are small in nature. So, the price of the fish determined through the bargaining power that exists between the actors depends on the supply and demand for fish, as well as the number of buyers and sellers. Fish traders have more bargaining power when they sell to consumers than when they buy from producers, because the bargaining power between producer and trader is almost equal, owing to the number of fish traders and producers being limited and small-scale in nature. Information flow within the rice-fish value chain is quite transparent. All the actors get information from each other as almost all have the access to mobile phones (whether their own or nearby neighbours/shop/market). Although there are several laws and law-enforcing regulatory agencies to check the quality and standard of daily food (like fish) in Bangladesh, the fish value chain, 
especially in the urban areas, is still adulterated (especially by the traders) through the use of different poisonous chemicals (like formalin) to keep the fish fresh (Rahman 2013; Uddin et al. 2011). Commercial aquaculture, which passes through a long value chain, faces this problem in particularly severe terms. Fish produced under a rice-fish system are generally sold live/fresh and within a short time to the nearby market, nearby consumers or is consumed by the producing farmers without any major processing. Thus, large scale adoption and diffusion of the rice-fish system could be an instrument for tackling fish adulteration and the related health risks in Bangladesh. Farmers and fish traders report that they are not familiar with any standard issues. There are several (mainly government) institutions in Bangladesh that are related to the rice-fish value chain actors, like the Ministry of Agriculture (MOA), which supports farmers by providing extension services and technical knowhow other than aquaculture and fisheries, and the Ministry of Fisheries and Livestock, which provides more or less the same services to fisheries and livestock sectors. The Department of Fisheries (DOF) is specifically responsible for the fishery sector's overall activities (like extension, quality and standard inspection, etc.). There are several national organizations, like the Bangladesh Rice Research Institute (BRRI) and the Bangladesh Fisheries Research Institute (BFRI), international research organizations, like the WorldFish Center, and non-governmental organizations, like CARE, who also develop and disseminate rice and fishery-related technologies in Bangladesh. Most of the actors report that they perform their activities individually rather than in any association or group (like farmers or traders association, cooperatives). There are some communitybased organizations among the indigenous people, but most of them deal with socio-cultural problems which are sometimes indirectly linked with rice-fish value chain activities. Rice-fish value chain actors are not satisfied with the services of most of governmental organizations. So there is plenty of scope to strengthen the governmental organizations that could facilitate the adoption and diffusion of ricefish systems in Bangladesh.

Table 17.2 demonstrates the differences in labor use between rice cultivation and rice-monoculture. In a traditional double or triple subsistence rice monoculture system, total labor requirements are estimated at 209.46 person-days/ha, which is significantly lower than the labor requirements for a rice-fish system at 287.57 person-days/ha. Interestingly, the labour requirement for different operational activities in producing a rice-monoculture and a rice-fish system also shows significant differences between the systems. As with land preparation, cop establishment, feeding, harvesting, threshing, cleaning and processing and buying and selling of input-output all required significantly more labour under a rice-fish system compared to a rice monoculture. In contrast, fertilizer application, pesticide application and weeding required more labour under a rice-monoculture system compared to a rice-fish system. It is important to note that gendered employment opportunities in different operational activities under both systems are largely dominated by male and household labour supply. But a rice-fish system creates a significantly higher amount of gendered employment opportunities than a ricemonoculture system. Some of the operational activities in an extensive rice-fish 


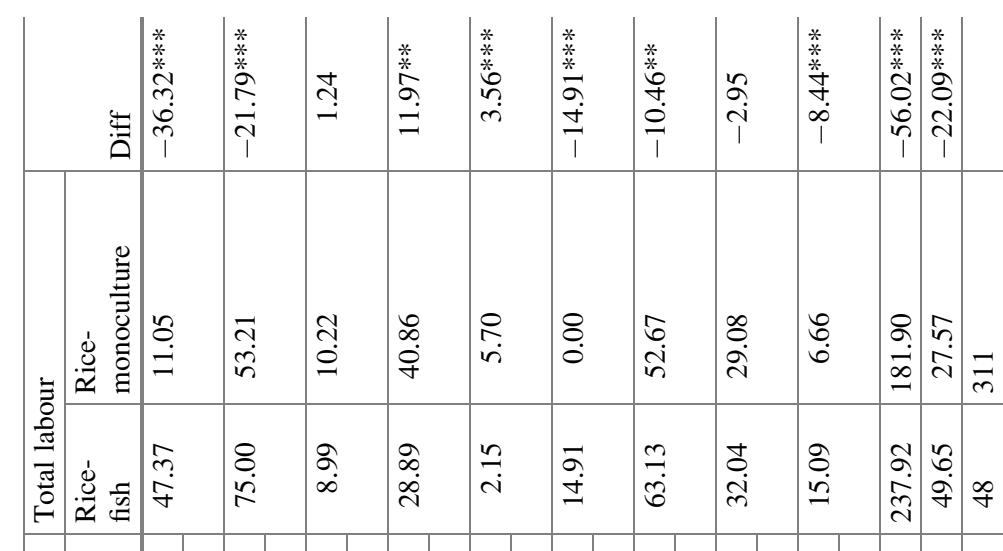

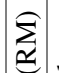

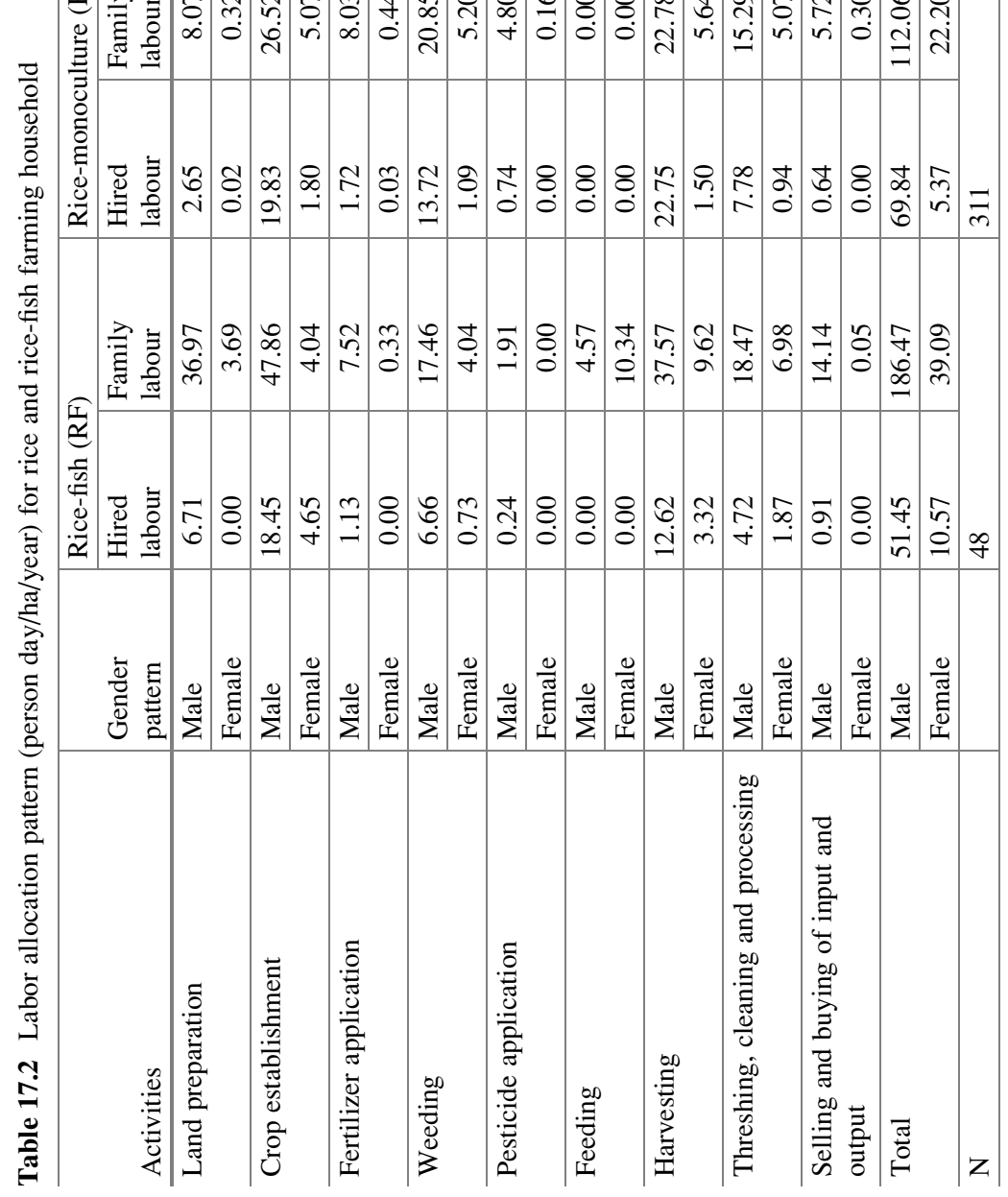


farming system (such as homemade feed preparation, feeding, and supervision) are associated with somewhat less drudgery compared to a rice monoculture system and are a source of employment for women labourers, especially for household women labourers.

Interestingly, value chain analysis findings indicate that fish produced under a rice-fish system and distributed within a very short time-period from harvest to final consumption due to the live/fresh nature of all sales are generally sold to consumers on the same day as the harvest, with almost zero post-harvest losses (which stands in contrast to many agricultural product value-chains, in which significant postharvest losses often occur in developing countries). Thus, it is evident that the ricefish value chain is an efficient and opportunistically gendered distribution system that produces close to the ultimate consumers.

\section{Gross Margin Analysis of Value Chain Actors}

Following a system-level approach for an entire agricultural year, detail cost and return from rice-fish and rice monoculture farming system are presented in Table 17.3. In the table, the economic feasibility of different farming systems is displayed on a yearly and per hectare basis. It is evident from the table that ricemonoculture farmers use human labour, seed/seedlings, ploughing, manure and chemical fertilizers, irrigation, pesticides and others as variable cost items which vary with the level of production. In addition to these variable cost items, rice-fish farmers use feed and fish fingerlings as additional variable inputs.

In the table, there is a significant difference in labor input between the farming systems. An integrated rice-fish farming system requires higher labor input due to additional works necessary to make the land suitable for a rice-fish system, like strengthening dikes and excavating refuges, ${ }^{2}$ as well as feeding and other operational activities down the line which are detailed in Table 17.2. The costs of ploughing and seedlings does not differ much between the farming systems. The stocking density of fish fingerlings for integrated rice-fish farmers is $92.48 \mathrm{~kg} / \mathrm{ha}$. Farmers reported that they prefer the comparatively larger size of fish fingerling because of their high survival rate, as well as their high growth rate. Although most of the indigenous farm household rice-fish systems contain abundant natural foods like phytoplankton, zooplankton, periphyton, and benthos, most farmers, nevertheless, use supplementary homemade/on-farm feed, like rice bran, wheat bran, mustard, oilcake and cow dung. Some farmers also use fishmeal and industrial concentrate feed along with their supplementary home-supplied feed. Interestingly, there is a significant difference in fertilization rate among culture systems. Integrated rice-fish farmers use less chemical fertilizers but more manure/inorganic

\footnotetext{
${ }^{2} \mathrm{~A}$ form of ditch, sump or small-size pond in a low-lying part of the rice field where fish can go when water is unavailable in the rest of the field, and therefore a good shelter for the fish.
} 


\begin{tabular}{|c|c|c|c|c|c|c|c|c|c|c|c|c|c|}
\hline 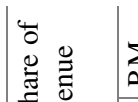 & $\sum$ & $\mid \begin{array}{l}\stackrel{g}{b} \\
\stackrel{\delta}{=}\end{array}$ & 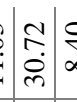 & \begin{tabular}{l|l}
$q$ & 0 \\
$\infty$ & 0 \\
$i$
\end{tabular} & 817 & 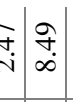 & $\stackrel{n}{r} \stackrel{8}{c}$ & : & 8 & 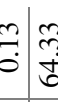 & & & \\
\hline 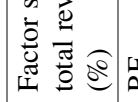 & $\approx$ & $\begin{array}{ll}0 & 8 \\
& 8 \\
\infty & \dot{n}\end{array}$ & $\begin{array}{l}\vec{\lambda} \\
\tilde{i}\end{array}$ & 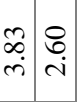 & $\frac{1}{6}$ & 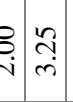 & 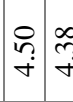 & ?ִ & & $\begin{array}{l}8 \\
0 \\
0\end{array}$ & & & \\
\hline$\overline{0}$ & & 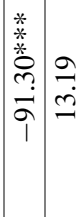 & 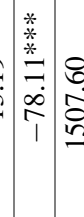 & 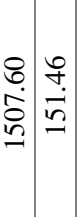 & 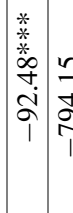 & 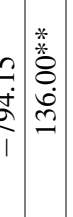 & $\begin{array}{c} \\
\infty \\
\infty \\
\stackrel{0}{0} \\
\vec{J} \\
\\
\end{array}$ & 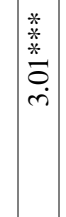 & & 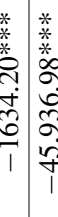 & & $\begin{array}{l}m \\
\vec{n} \\
\text { ते }\end{array}$ & 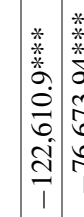 \\
\hline
\end{tabular}

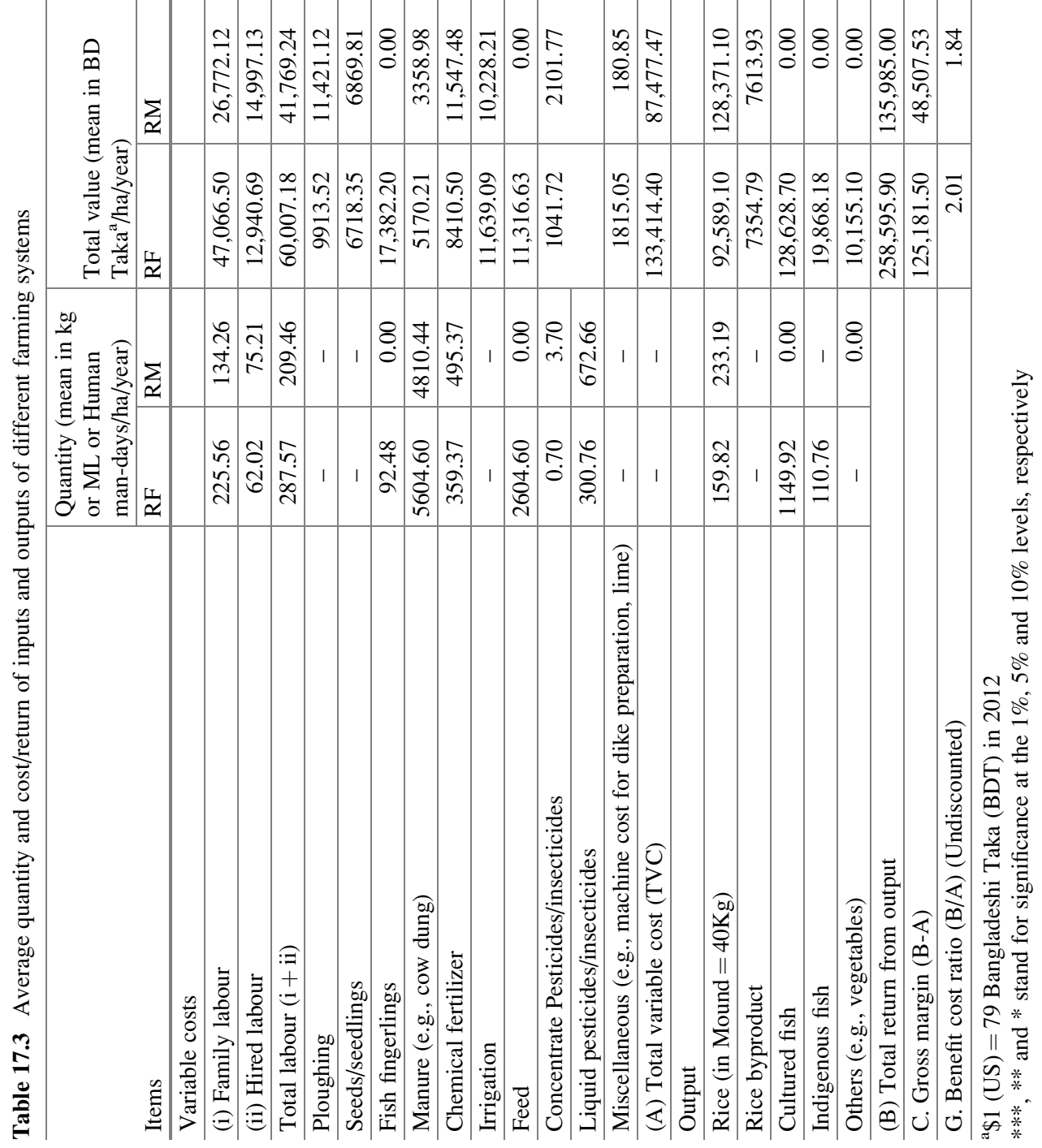


fertilizers, whereas the rice-monoculture farmers do the opposite. The integrated rice-fish farmers use of less chemical fertilizer may be due to the presence of fish in the rice field, which increases soil fertility. Quite surprisingly, farmers of both farming systems use liquid as well as concentrated pesticides to prevent pests and diseases. But rice monoculture farmers use significantly higher amounts of liquid and concentrated pesticides compared to rice-fish farmers. Rice-fish farmers mostly use liquid pesticides. Farmers reported that there are some pesticides which do not affect fish survival rate and, consequently, they use those pesticides without knowing the residual effects. Additionally, rice-fish farmers have to expend further miscellaneous costs, which include land modification both before and after the rice-fish harvest, while some farmers produce dike vegetables which incur their own cost items, like vegetable seeds, bamboo, rope, etc.

According to our survey, the highest average annual productivity of rice per hectare is found in rice monoculture (233.19 mound equivalent to $233.19 * 40=9327.60 \mathrm{~kg}$ ), followed by integrated farming (159.82 mound equivalent to $159.82 * 40=6392.80 \mathrm{~kg}$ ). There is a significant difference in rice yield between the farming systems, which may be due to the differences in inputs (seed, fertilizer and pesticides) and management and technical skills. Quite a number of farmers reported that rice does not grow well in the rice-fish system and also complained that fish sometimes destroy the rice. Halwart and Gupta (2004) reported that bottom feeding carp, especially the common, herbivorous species such as the grass carp, uproot and eat whole rice plants if those species are stocked before the rice plants develop a good root system, as well as if the fingerlings of those species stocked are of the larger sizes. Thus, fingerling management is crucial for a rice-fish system, especially for rice productivity in that system. The average annual cultured and indigenous fish yield reported by rice-fish farmers is 1149.92 and $110.76 \mathrm{~kg} / \mathrm{ha}$. The rice-fish farmers who cultivate vegetables in their dike, while incurring additional costs also find additional income opportunity. Overall, the total return and gross margins differ significantly between the systems. Although the rice-fish farmer's rice yield is significantly lower than that of the rice-monoculture farmer, a rice-fish farmer's total return, as well as gross margin, is significantly higher. Thus, rice yield loss is outweighed by the higher return from fish under a rice-fish system. The resultant increase in gross margins for rice-fish technology results in a benefit cost ratio of 2.01. The result simply indicates that, holding other factors constant, for every additional Bangladeshi taka invested in rice-fish technology, the gross margin will be increased by more than two times, which is quite higher than that of investment in rice-monoculture. The results indicate that, at the farm level, rice-fish technology appears to be an economically viable alternative to rice-monoculture.

A closer look at the factor share of total revenue of these farming systems provides further insight into their economic viability. Factor shares of total revenue and total variable cost explain how the benefits shared among the production factors, as well as input intensity and input prices, influence the costs and returns of different systems. The analysis in Table 17.3 identifies labor, fingerlings, feed, and irrigation as the most costly inputs, as well most of the benefits shared among 
them in rice-fish systems, whereas in rice-monoculture systems, labour, fertilizer, ploughing, irrigation and seed are the most costly inputs and most of the benefits are also shared among them. Overall total return shared among the variable costa is higher in a rice-monoculture system compared to a rice-fish system. This implies that a rice-fish system and its fixed factors get a higher profit margin share than a rice-monoculture system.

Similar to Tables 17.3 and 17.4 presents the cost and return, as well as factor share, for a rice-fish system value chain with backward and forward linkage actors. As we have seen in the value chain maps, a rice-fish value chain is not very long and, consequently, not many value-added functions are carried out by the participating actors. Thus, the cost items list for backward and forward linkage actors, such as fingerling traders, fisherman, and fish traders, is not so long. Labour, transport and food are the main cost items. The quantity and value of the variable cost items are almost the same for all actors, but total return, as well as gross margin, varies among the actors. This is due to the differences in average number of days the activities run per year, the average quantity dealt with per day, and the average buying and selling price differences among the actors. For fisherman, that is largely influenced by the average catch or the average share of fish they get catching fish in a group. All the actors reported the seasonality of their activities due to irregular fish supply, water shortage (drought) and a decrease in common pull fishery sources like rivers, canals, etc. Thus, those actors cannot rely on these activities for their livelihood, which sometimes demotivates them to engage in them, or may even cause them to abandon the activities altogether. Among these, the three actors' gross margin is higher for fish traders, followed by fingerling traders and fishermen. The gross margin benefit cost ratio shows the same trend.

Analysis of factor shares of total return and total variable cost (in parenthesis) in Table 17.4 shows that labor and transport costs are the two most costly inputs in fingerling trading, fishing (fishermen) and fish trading. These two inputs also get the most share of total return from the respective business activities. These factor shares give the idea that these activities may have significant potential for creditconstrained and limited-market-access households, and even for landless marginalized households, because labour cost is the major share of total variable cost.

\section{Partial Budgeting}

The potentiality of any technological innovation can be evaluated by its private benefits and costs; a technological innovation is said to be economically feasible if the benefits from the technology outweigh the costs. Thus, to assess the relative potentiality of rice-fish technology over the performance of the rice-monoculture practices, a partial budget was constructed using the cost and benefit information derived from the interviews with farmers during field surveys. The findings of the analysis are shown in Table 17.5. 


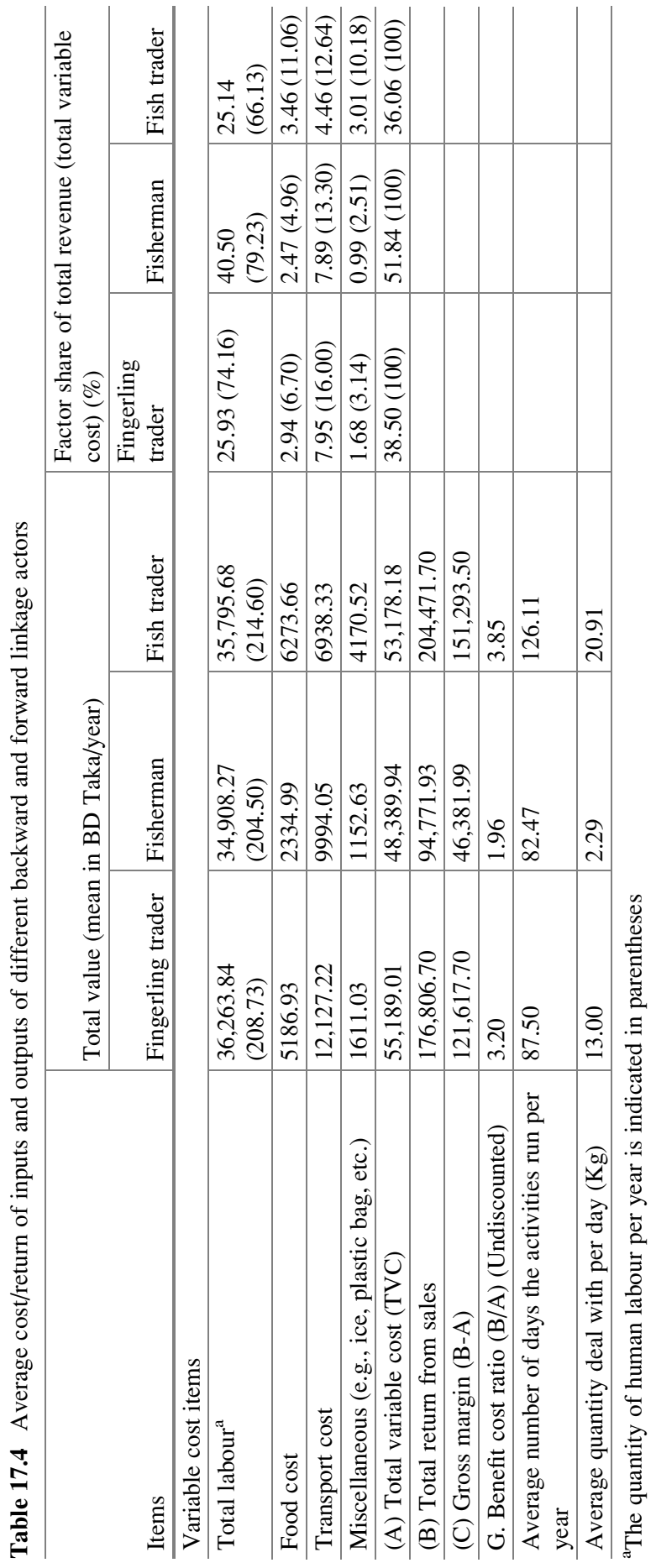


Table 17.5 Partial budgeting: net change of gross margin due to introduction of fish into the rice field instead of a rice monoculture

\begin{tabular}{l|l|l|l}
\hline Costs & Tk/ha/year & Benefits & $\begin{array}{l}\text { Tk/ha/ } \\
\text { year }\end{array}$ \\
\hline 1. Cost incurred for rice-fish & $133,414.4$ & $\begin{array}{l}\text { 1. Cost saved by not doing rice } \\
\text { mono-culture }\end{array}$ & $87,477.47$ \\
\hline $\begin{array}{l}\text { 2. Revenue forgone by not doing } \\
\text { rice mono-culture }\end{array}$ & 135,985 & $\begin{array}{l}\text { 2. Revenue earned from rice- } \\
\text { fish }\end{array}$ & $258,595.9$ \\
\hline Net change $(++)$ & $76,673.97$ & & $346,073.4$ \\
\hline Total & $346,073.4$ & Total &
\end{tabular}

It is evident from Table 17.5 that introduction of fish into a rice field increases cost as well as benefit, but the benefits outweigh the costs. Thus, the net change in farm income due to introduction of fish into the rice field instead of a rice monoculture is positive and can amount to 76,673.97 Bangladeshi Taka per year per hectare. This additional benefit is only at the farm level, but if we take into account the additional benefits of other rice-fish value chain actors, then the figure would be much higher. Ultimately, the net benefit of rice-fish systems, primarily, is the additional income from fish that is earned by smallholder indigenous farmers without a significant loss of income or food security from forgone rice cultivation.

\section{SWOT of Integrated Rice-Fish Farming System Value Chain}

A summary of key elements in terms of strengths, weaknesses, opportunities, and threats (SWOT) characterizing the integrated rice-fish farming system has been derived from stakeholder interactions, field observation, in-depth farm household surveys and literature review, and is presented in Table 17.6. SWOT analysis explores how the rice-fish value-chain performance could be further improved by identifying the critical factors impacting value-chain performance. Table 17.6 provides a brief summary of the key issues that impact the sector. All of the issues included in the table, and details discussed in the subsequent section, represent potential areas of action by the value-chain itself and by those relevant factors outside of it (e.g., policy-makers, research organizations and extension agents) to improve value-chain performance in this sector.

\section{Strengths}

The rice-fish farming system is feasible virtually throughout the country's irrigated and rain-fed rice areas, without the necessity for major adjustment to traditional production methods. The rice-fish farming system is not new, but there are numerous potentialities for improvement by introducing innovation to the system. Fish 
Table 17.6 SWOT framework related to adoption and diffusion of rice-fish technology in Bangladesh

\begin{tabular}{|c|c|}
\hline Strength (S) & Weakness (W) \\
\hline $\begin{array}{l}\text { Sustainable agricultural development is on the } \\
\text { political agenda } \\
\text { Ecologically and environmentally sound sus- } \\
\text { tainable intensification option } \\
\text { Multifunctional agricultural system with mul- } \\
\text { tiple benefits } \\
\text { Can act as an important element of integrated } \\
\text { pest management (IPM) } \\
\text { Needs less fertilizer, pesticides and herbicides } \\
\text { Efficient and complementary utilization of } \\
\text { scarce land and water resources } \\
\text { Increases soil fertility } \\
\text { Integrated resource management options } \\
\text { Use of rice field for fish seed/fingerling pro- } \\
\text { duction } \\
\text { Rice and fish together as a sources of carbo- } \\
\text { hydrate and animal protein } \\
\text { Fish for daily home consumption } \\
\text { Women in the family can supervise } \\
\text { Traditional importance (rice and fish) in rural } \\
\text { Bangladeshi livelihoods } \\
\text { Creates employment opportunities during lean } \\
\text { periods } \\
\text { Rice-fish technology has a pro-poor focus, and } \\
\text { can benefit small-scale farmers, the landless, } \\
\text { land owners, fishermen, producers, and other } \\
\text { value chain actors } \\
\text { Several direct and indirect policies support } \\
\text { rice-fish system improvement in Bangladesh, } \\
\text { like five-year plans, Country Investment Plan, } \\
\text { PRSP, Protection and Conservation of Fish } \\
\text { Act, National Fisheries Policy, National Water } \\
\text { Policy, National Agricultural Policy, National } \\
\text { Land Use Policy and New Agricultural Exten- } \\
\text { sion Policy } \\
\text { Several agencies involved in crop and fishery } \\
\text { management and officially concerned with } \\
\text { developing crop and fishery technologies, spe- } \\
\text { cifically rice-fish technologies among farmers } \\
\text { Availability of competent authorities BFRI } \\
\text { (fisheries), BRRI (Rice) and WFC (Fisheries } \\
\text { and aquaculture), } \\
\text { Existence of DEA and NARS apex organiza- } \\
\text { tion BARC to disseminate rice and fishery } \\
\text { technologies and to provide a platform for dis- } \\
\text { cussion between different institutions }\end{array}$ & $\begin{array}{l}\text { No strategy is defined for the implementation } \\
\text { of sustainable agricultural development } \\
\text { Initial cost of preparation is high for poor } \\
\text { farmers } \\
\text { Needs continuous supervision } \\
\text { Needs more labour } \\
\text { Needs more technical knowledge } \\
\text { Lack of backward and forward linkage actors } \\
\text { and their inputs } \\
\text { Lack of wider irrigation coverage } \\
\text { Confusion and duplication in responsibilities } \\
\text { of the various agencies involved in rice and } \\
\text { fishery management at central and local levels } \\
\text { Lack of efficient and motivated expertise, } \\
\text { resources, budget and equipment for public } \\
\text { agencies } \\
\text { Lack of system thinking and coordination } \\
\text { among the crop and fishery-related institutions } \\
\text { like ministries, research and extension orga- } \\
\text { nizations } \\
\text { Lack of system thinking and coordination } \\
\text { among different policies and their application } \\
\text { Historical lack of investment in the social, } \\
\text { economic, and policy dimensions of rice-fish } \\
\text { system } \\
\text { Limited or absent availability of component } \\
\text { technologies within different rice-fish ecolo- } \\
\text { gies } \\
\text { Less than timely availability of quality fin- } \\
\text { gerlings } \\
\text { Lack of post-harvest processing facilities and } \\
\text { storage } \\
\text { Weak and inadequate infrastructure } \\
\text { Lack of technical knowledge needed for } \\
\text { proper adoption and diffusion } \\
\text { Need for suitable bio-physical conditions } \\
\text { Need for stronger collaboration among } \\
\text { policymakers and development practitioners } \\
\text { (related to rice, fish, land, water, and } \\
\text { environment) }\end{array}$ \\
\hline Opportunities $(\mathrm{O})$ & Threat (T) \\
\hline $\begin{array}{l}\text { Opportunity to obtain financial and technical } \\
\text { assistance from international donors to enhance }\end{array}$ & $\begin{array}{l}\text { Risk and uncertainty from climate variability, } \\
\text { flooding, drought, poaching, poisoning, etc. }\end{array}$ \\
\hline
\end{tabular}


Table 17.6 (continued)

capacities of public organizations and manpower for proper adoption and diffusion of rice-fish technology

Further increases rice and fish yield sustainably

Uses homemade waste feed

More employment opportunities

Increases backward and forward linkages

Increases acres to irrigated and rainfed rice field

Food and nutrition security and self sufficiency

Reduces/alleviates hidden hunger problems

Uses extensive extension system

Uses scarce land and water resources optimally

Possibility of conducting successful communication campaign for public health concern about negative consequences of rice monoculture and positive benefits of rice-fish system Sustainable development through sustainable intensification options

Potential to satisfy consumption culture of the people

Potential to introduce innovation in rice-fish system, such as improvements in genetic potential and management practices, can potentially contribute to increasing agricultural productivity and food and nutrition security Potential to conserve nutrient rich small indigenous species (SIS)

Increases dietary and crop diversity

Increases agricultural labour employment Supports institutional innovation like collective management, community-based management to manage the common pool resources Develops public-private partnerships for effective implementation of rice-fish systems Introduces integrated pest management (IPM) into rice-fish system

Introduces agricultural insurance to overcome the loss associated with flood and drought
Theft, disease and fish predators, such as snakes and kakra

Increasing trend towards landlessness

Small farm size/land man ratio

High production cost

Increases use of fertilizer, pesticides, insecticides, herbicides and irrigation facility ownership

Significantly labor-intensive production systems

Unfavorable property rights of land, especially for the tenant farmers

Lack of supply of quality feed and high price level

Low education and farmers unconcerned with the long-term environmental benefits

Increasing tendency towards tenant farmers and absentee landlords

Poor extension service and lack of information among farmers

Access to timely credit, high interest rate and unfavorable repayment schedules

Higher fish mortality due to poor water quality, water pollution, turbidity, low water levels and high water temperatures

Weak governance in extension systems

Lack of access to land and water resources

Land fragmentation due to high population growth

Unfavorable land tenure systems and absence of successful land reforms

Conservative societal structure due to low education, especially for women

Sources: Personal stakeholder interactions, field observation, in-depth farm household surveys and literature review of Nabi (2008), Frei and Becker (2005), Ahmed and Garnett (2011), Ahmed et al. (2011), IFPRI (2010), Dey et al. (2013), Halwart and Gupta (2004)

seed production, vegetable production, and fruit and tree production could be made easier under such a system. The main consumption item of the Bangladeshi people, especially that of the marginalized poor, is rice and fish, a fact which can drive the adoption and diffusion of rice-fish technology to keep pace with traditional food demand. The rice-fish farming system is a socio-economic and environmentally friendly sustainable intensification option for sustainable development compared to rice monoculture. It has multiple comparative benefits: improving public health by 
controlling rice pests, weeds, mosquitoes, and snails; reducing the use of chemical fertilizers and pesticides, insecticides and herbicides which will consequently increase biodiversity; nutrient recycling; fish as a tool of an integrated pest management (IPM) system; intensive and complementary use of land and water resources; improvement in crop diversification, which consequently improves dietary diversity; improvement in soil fertility by generating nitrogen and phosphorus, etc. In addition, rice-fish technology creates employment opportunities during the lean season in particular, and more gendered employment opportunities in general, compared to rice monoculture. As rice-fish farming land in Bangladesh tends to be situated very close to the homestead, the women in the family can supervise and attend to some of the labor, like feeding. All of these are solid strengths of rice-fish technology, which can enhance greater adoption and diffusion of the technique in Bangladesh.

In the value chain map, we have seen that the rice-fish value chain is quite short and that most of the farmers sell their fish live and fresh, typically on the same day of harvest. Thus, increasing consumer awareness about the health and quality inherent in the system, along with catering to their preference for quality food products, could provide better return to the rice-fish producers and better quality fish to the consumers. Emphasis on the paradigm of intensification of sustainability in rice-fish farming systems in several national policies such as the 5-year plans, the Country Investment Plan, the PRSP, the Protection and Conservation of Fish Act, the National Fisheries Policy, the National Water Policy, the National Agricultural Policy, the National Land Use Policy and the New Agricultural Extension Policy is a good strength for the diffusion of rice-fish technology. The traditional importance of rice and fish in the rural livelihoods and food culture (mache vate benglai) of the Bangladeshi people, especially poor rural households, are the major drivers for adoption and diffusion of rice-fish systems in Bangladesh. In the value chain analysis, we have seen that the rice-fish value chain creates additional backward and forward linkages compared to rice monoculture, which, as a consequence, creates additional livelihood opportunities for marginalized and extremely poor households. In Bangladesh, there are several institutions involved in crop and fishery management that are officially concerned with developing crop and fishery technologies, specifically rice-fish technologies among farmers. In addition, there are some specialized competent organizations like BFRI for fisheries, BRRI for rice and WFC for fisheries management, as well DEA and DOF, which have wide networks throughout Bangladesh to disseminate rice and fishery technologies and provide extension services to farmers. Furthermore, there is the NARS apex organization BARC, which acts as a platform for discussion between different institutions and coordinates and monitors different organization activities. Thus, Bangladesh has quite a good number of institutions related to rice-fish technology, which indicates a strong institutional framework for adoption and diffusion of ricefish technology throughout potential areas in Bangladesh. 


\section{Weakness}

There exist some weaknesses in the technology itself, and at the policy and institutional levels, that limit farmers' ability to take full advantage of the abovementioned strengths. There are certain modifications necessary to make rice fields suitable for fish culture which involve costs that are sometimes below farmers' ability to invest, especially the marginalized, poor, indigenous, etc. Thus, initial investment cost is the major weakness for rice-fish technology to be a pro-poor innovation. The rice-fish field needs continuous supervision; otherwise, fish can easily be stolen by others. This supervision and feeding, land preparation and the catching of fish requires far more labour compared to rice monoculture. For adoption of rice-fish technology, farmers need suitable bio-physical conditions, like the water retention capacity of soil and soil quality (soil texture, topography and depth) and a guarantee that they will not be unduly hindered by neighboring farmers' behavior, such as the spilling of fertilizer and insecticide into their plots. Without water, rice-fish technology adoption will not be possible, but the water supply, especially during the irrigation season, does not cover the entire riceproducing areas of Bangladesh. Rice-fish fields require a great amount of and more continuous water than rice monoculture does. In Bangladesh, there is a well-established water market, thus, most farmers have to depend on water sellers, which sometimes works as a constraint or weakness for rice-fish technology. For successful adoption and diffusion of rice-fish technology, it is very important that there be technical knowledge of a sort which is very often lacking in the uneducated marginalized poor farmers of Bangladesh. Technical knowledge related to rice-fish technology adoption includes modification of the farm, timing of introduction of fingerling stock into the rice field, the combination of fingerling species, selection of suitable fingerling species, etc.

Depending on the rice-fish farming system characteristics, a farmer needs good quality and timely availability of fingerlings to stock the rice field, something which is very often lacking, especially in the dry season, and costly for poor smallholder farmers. There are backward and forward linkage actors involved in the rice-fish value chain, but the number of these actors is very few in Bangladesh. It has been reported that these professions are not recognized as dignified jobs in the society, which discourages people from engaging in these professions. That constrains the fingerling and fish trading businesses, as well as the overall rice-fish technology.

Policies and institutions related to rice-fish farming in Bangladesh also have certain weaknesses that inhibit rice-fish farming adoption and diffusion. A number of policies have been set forth towards the goal of sustainable agricultural development, but no definitive strategy has been established for the implementation of such development. Generally, there is a lack of system thinking and coordination among different policies and their application in Bangladesh, as in many other developing countries. Likewise, there are a number of organizations involved in rice and fishery management at central and local levels, but the duties and responsibilities of these organizations are not well defined, which leads to confusion and 
duplication. The organizations lack efficient and motivated expertise, resources, budget and equipment to promote rice-fish research and dissemination, and, as with the policies, there is little to no system thinking and coordination among them. Other than these policies and organizations, historically, investment in the social, economic, and policy dimensions of rice-fish systems is negligible. As a result, post-harvest processing facilities are not well developed or widespread in Bangladesh.

\section{Opportunities}

There exists good opportunity for rice-fish farming in the rural areas of the country, as most of the farmers are engaged in rice farming and there are available low-lying rice fields suitable for rice-fish farming. Growing awareness among fish consumers about quality and the huge demand for live and fresh fish, as well as increasing purchasing power, could provide the ramification for the development of rice-fish farming. Rice-fish farming requires more labour input than traditional and modern rice farming methods. Thus, Bangladesh, which has a very large amount of female unemployment and under-employment, will find rice-fish farming attractive. Moreover, the problem of unemployment during lean periods, which causes seasonal hunger like monga, will also be mitigated because of diversification in farming, with different stoking and harvesting schedules resulting in the requirement of a relatively high labour input. Protection of the ecosystem, flora, fauna and increased biodiversity, along with the resulting benefits to all humans and living things, are great advantages of rice-fish farming which are yet to be properly accounted for. There are numerous opportunities to obtain financial and technical assistance from international donors to enhance the capacity of public organizations and their manpower to enact proper adoption and diffusion of rice-fish technology in particular and agricultural technology in general. Introducing fish into rice fields creates opportunities for the sustainable use of scarce land water resources and produces rice (carbohydrates) and fish (animal protein) together, which can ensure food and nutrition security in Bangladesh. It also creates opportunities to increase the rice yield sustainably, which can ensure keeping pace with the soaring demand for food, chiefly rice, in Bangladesh. Bangladesh is one of the 34 countries which faces severe nutrition insecurity, especially hidden hunger problems (Ruel and Alderman 2013). The fish species grown in the rice fields, particularly SIS fish, are rich in micronutrients which can reduce or alleviate hidden hunger problems in Bangladesh and other developing countries. In the rice-fish system, and in the subsistence system most of all, farmers can use different home waste and homemade feed (e.g., waste rice, wheat and its bran, etc.) as fish feed, which can reduce feed cost. In the value chain, we have seen that rice-fish systems create additional channels, actors and networks which ultimately create considerable livelihoods and employment opportunities, especially for the marginalized poor. Although rice-fish farming is a technology with a lot of potential in terms of socio-economic 
profitability, gendered employment generation and food and nutrition security enhancement, its adoption and diffusion is very low. Different estimates suggest that there are huge suitable biophysical areas in Bangladesh where rice-fish technology could easily be adopted and diffused. Additionally, by introducing irrigation technologies, these areas could be further increased.

In Bangladesh, the extension systems of the DEA and DOF are quite extensive and cover almost all sub-districts, so it would be possible to use these huge extension systems for dissemination of rice-fish systems throughout potential areas in Bangladesh. By engaging these extension systems and other institutions related to rice and fish, it is possible to conduct successful communication campaigns about the public health concerns regarding the negative consequences of rice monoculture and the positive benefits of rice-fish systems, which would enhance adoption and diffusion of these systems in Bangladesh. It would also be possible to develop public-private partnerships for the effective implementation of rice-fish systems. Nutrient rich SIS fish are nearly extinct due to the introduction of green revolution technologies. Thus, rice-fish systems create the opportunity to conserve these indigenous species. In this system, it is possible to introduce integrated pest management (IPM) techniques which could reduce the cost of production, as well as being environmentally friendly and good for conserving the different fish species, SIS in particular. Rice-fish systems increase crop diversity by introducing fish into the rice fields, as well as making it possible to introduce vegetables into the dike, further increasing income and dietary diversity for poor rural farmers. Due to this diversity, a rice-fish system can be a climate resilient farming system. Although rice-fish systems are traditionally practiced in Asia, including Bangladesh, it is possible to introduce innovation into such a system, like improvements in genetic potential and management practices which can potentially contribute to increasing agricultural productivity and food and nutrition security in the country. The ricefish system enhances institutional innovation like collective management or community-based management to manage the common pool resources, like water, especially in the low lying areas during the rainy season. As the rice-fish system is quite vulnerable to climatic shocks like drought and flood, it is possible to introduce agricultural insurance to overcome the loss associated with these shocks, which can also enhance adoption and diffusion of the systems.

\section{Threats}

Although there are tremendous strengths and opportunities associated with the adoption of rice-fish farming in Bangladesh, there are also some threatening factors that have been identified that hinder adoption and diffusion of the technology in Bangladesh. One obvious threat is the risk and uncertainty associated with climate variability, flooding, drought, poaching, poisoning, etc., all of which are very common phenomenon in Bangladesh. Other than these, theft, disease and predators such as snakes and kakra that eat fish from the rice field can cause huge economic 
losses. Poor water quality, water pollution, turbidity, low water levels and high water temperatures also cause higher fish mortality rates, which ultimately reduce motivation to continue using the system. In Bangladesh, deteriorating access to increasingly scarce natural resources (such as water and land) are also major threats for the expansion of rice-fish farming, especially among poor people. Surprisingly, in Bangladesh, landlessness, tenant farmers and absentee landlords are increasing day by day (Ahmed et al. 2013). But the land tenure system and land property rights, especially property rights for tenant farmers, are quite unfavourable towards expansion of rice-fish systems in Bangladesh. Due to mounting population growth, farm size/land-to-man ratio is declining (with land fragmentation increasing) and the increasing price of farm inputs keeps production costs in an upward trend which also threatens this type of farming, especially for the marginalized farm households in Bangladesh. To keep pace with soaring demand for food, rice in particular, Bangladeshi rice farmers have intensified their rice monoculture (up to three times in a year) by increasing use of fertilizer, pesticides, insecticides, and herbicides, which are all major threats for introducing fish into the rice. Irrigation, chiefly in the dry season, is a mandatory input for rice monoculture as well as for rice-fish systems, but in Bangladesh, not all the farmers have their own irrigation facilities. Most of them depend on the irrigation water market, which is also a threat to the adoption of rice-fish systems, because these systems need comparatively greater and more continuous supplies of water, something that can be very difficult without their own irrigation facilities.

Although labour intensive, rice-fish systems create employment opportunities; however, this too becomes a threat, because the cost of labour in Bangladesh continues to increase, and as an emerging economy's labour supply shifts from agriculture to non-agricultural sectors, labour crises in the agricultural sector have arisen in recent years. For large-scale and commercial rice-fish systems, additional feed is needed which farmers would normally have to buy from feed traders in the market. As rice-fish systems, as well as pond fish production, are not widespread, being mainly concentrated in certain regions, timely availability of quality feed also threatens greater adoption and diffusion of the technique. In addition, feed price is very high, and increasing, which increases production cost and is ultimately burdensome for poor subsistence farmers. Credit facilities, especially for agricultural purposes, are very weak, and interest rates are very high. Terms and conditions for credit are not favourable for agriculture, because farmers cannot repay within 1 week, agricultural practices like rice-fish systems needing a minimum gestation period and being seasonal. As we already mentioned, rice-fish technology is quite knowledge intensive and technical, thus, farmers need education, but the education levels in general, and those of farmers in particular, are very low. Low education is also sometimes linked with farmers' awareness of the positive and negative effects of any given technology, such as the comparative environmental benefit of rice-fish technology over rice monoculture. Good extension services could fill those gaps, but the extension services in Bangladesh are also very poor, although they have fairly wide networks. Governance in extension systems is very weak, which 
ultimately threatens the overall adoption and diffusion of agricultural technology and rice-fish systems in particular.

\section{Conclusions and Policy Implications}

Like many other Asian countries, Bangladesh is considered to be a "rice-fish" society, because both rice and fish are part and parcel of the Bangladeshi people's food culture, which has led to a popular Bengali saying, "Mache bhate Bangali," (in English, "Rice and fish make a Bengali.") (Dey et al. 2013). Some estimates suggest that Bangladesh has 2-3 million hectares of land with the potential for ricefish production systems (ADB 2005; Dey et al. 2013; Ahmed and Garnett 2010; Dey and Prein 2006). A recent estimate indicates that about 0.18 million hectares of land are under use for rice-fish systems, which is much lower than the potential areas (Dey et al. 2013). Thus, one can raise the question as to its overall performance and the potential impeding factors that hinder adoption and diffusion into potential areas. This article attempts to provide a snapshot of the performance of Bangladesh's rice-fish systems by using a value chain analysis framework with detailed data from recent surveys on rice-fish value chain actors among the indigenous people of Bangladesh.

The chapter examines the financial performance of different actors in rice-fish systems and the myriad of factors determining such performance. Financial performance was measured by gross margin analysis. The article further investigated whether integration of fish into rice fields would improve profitability and justify a program for farming system improvement through the introduction of innovation. A partial budget analysis was conducted for two different rice production systems: a conventional rice production system under the green revolution regime (monoculture farm model), and an existing rice farm that diversified into aquaculture using the land and water resources of established rice farms (integrated farm model). Moreover, this chapter also explores the internal and external factors of the rice-fish system to further improve that system and encourage large-scale adoption and diffusion of rice-fish technologies. SWOT analysis was used to identify the level of rice-fish technology, as well as associated policy- and institutional-level strengths, weaknesses, opportunities and threats which can help towards future strategy building in regard to rice-fish technology adoption and diffusion.

Findings indicate that rice-fish systems offer considerable potential for increasing overall agricultural productivity and farm incomes in Bangladesh. Results also show that the rice-fish system value chain provides opportunity for landless, extremely poor households to participate in backward and forward linkage value chain activities in a profitable manner. To the best of our knowledge, a detailed cost and return survey of the rice-fish sub-sectors value chain similar to the one presented in this chapter has not previously been done in Bangladesh or elsewhere in countries with rice-fish potential. This paper has demonstrated that the rice-fish sector creates a very considerable level of profitable business opportunities at each 
stage of the value chain, and provides gendered employment opportunities, especially in the rice-fish production stage. Employment within the rice-fish value chain is further shaped by the social and institutional context within which it operates. Although rice-fish systems create opportunities for female labour, the affect they may have on household labour allocation decisions and womens' reproduction needs more research. Partial budgeting analysis supports the above findings that the rice-fish system is an economically sustainable competitive alternative to rice monoculture in Bangladesh. In addition to the empowerment of vale chain actors, rice-fish farming also benefits the local community and enhances rural economic growth.

However, rice-fish technology faces a number of significant challenges, and it is noteworthy that the technology exists in a rather sluggish manner within Bangladesh. Some innovative farm experimentation, private initiation by such organizations as the WFC, and motivation by NGOs like CARE, are the key impetus for bringing the rice-fish sector into mainstream agriculture in Bangladesh. There is a virtual lack of government support for the rice-fish farmers and overall value chain development. The high initial costs of rice-fish farming in terms of land, labour, fingerlings and feed, and land modification are major constraints to increasing pro-poor adoption and diffusion in the rice-fish production sector. In the short run, other rice-fish value chain actors have fewer barriers to entry and, if combined with rice-fish farming, the benefits could be significantly higher in the long run for poor farmers, despite the high initial cost outlay.

The traditional strengths of the technology are abundant water, fertile soil, strong research and extension institutions, expanded infrastructure and the encouragement of government policies to increase private-sector participation, which more than make up for its weaknesses and threats. Indeed, the enormous opportunities for further improvements in rice-fish technology and its value-chain performance provide a strong argument for action by the private sector within the value-chain, and by the government in the form of supportive policy and legislation (on issues such as property rights in land tenure, access to credit and markets, access and quality of irrigated water and feed, infrastructure, and public and private human capacity development and training). Such action would serve both to safeguard the current status of adoption and diffusion and to derive the benefits from it and further increase its adoption and diffusion, and the subsequent benefits, in the future.

Value-chain analysis has not been widely used to assess the ex-ante performance of integrated farming systems in general and integrated rice-fish technology in particular, with an aim towards further development of the sector. This paper has showed how the value chain analysis, together with SWOT analysis, helps us to understand the financial and social benefits generated by rice-fish technology, and to identify the crucial factors that hinder large scale adoption and diffusion and the overall performance of value chain development. Better understanding of these crucial factors can help to design the necessary policy and institutional actions and innovations that will increase adoption and diffusion, as well as the overall development of the sector. 
Thus, this chapter emphasizes that the rice-fish-based farming system and its value chain development in potential developing countries could give momentum to the sustainable intensification paradigm, as the technology has traditional strengths and opportunities for further development, although its constraints (weaknesses and threats) should be properly acknowledged in order to make it happen. The important contribution of this study is, as this study was done among the nation's indigenous people, to help better design agricultural intervention to reduce extreme poverty and marginality in Bangladesh and possibly other countries in Asia and Africa that have similar socioeconomic, agro-ecological, and institutional settings.

Acknowledgement The study was supported by the German Academic Exchange Service (DAAD) and Dr. Hermann Eiselen's Doctoral Programm of the Foundation fiat panis research fellowship. It is a part of the first author's doctoral research at the Center for Development Research (ZEF), University of Bonn, Germany. The views and opinions expressed herein are solely those of the authors.

Open Access This chapter is distributed under the terms of the Creative Commons AttributionNoncommercial 2.5 License (http://creativecommons.org/licenses/by-nc/2.5/) which permits any noncommercial use, distribution, and reproduction in any medium, provided the original author(s) and source are credited.

The images or other third party material in this chapter are included in the work's Creative Commons license, unless indicated otherwise in the credit line; if such material is not included in the work's Creative Commons license and the respective action is not permitted by statutory regulation, users will need to obtain permission from the license holder to duplicate, adapt or reproduce the material.

\section{References}

ADB (2005) An evaluation of small-scale freshwater rural aquaculture development for poverty reduction. Asian Development Bank, Manila

Adelman I, Taylor JE, Vogel S (1988) Life in a Mexican village: a SAM perspective. J Dev Stud 25(1):5-24

Ahmed N, Garnett ST (2010) Sustainability of freshwater prawn farming in rice fields in southwest Bangladesh. J Sustain Agric 34(6):659-679

Ahmed N, Garnett ST (2011) Integrated rice-fish farming in Bangladesh: meeting the challenges of food security. Food Secur 3(1):81-92

Ahmed N, Zander KK, Garnett ST (2011) Socioeconomic aspects of rice-fish farming in Bangladesh: opportunities, challenges and production efficiency. Aust J Agric Resour Econ 55(2):199-219

Ahmed AU, Ahmad K, Chou V, Hernandez R, Menon P, Naeem F, Naher F, Quabili W, Sraboni E, Yu B, Hassan Z (2013) The status of food security in the feed the future zone and other regions of Bangladesh: results from the 2011-2012 Bangladesh Integrated Household Survey. Project report submitted to the US Agency for International Development. International Food Policy Research Institute, Dhaka. http://www.ifpri.org/sites/default/files/publications/bihstr.pdf

Alam MF, Thomson KJ (2001) Current constraints and future possibilities for Bangladesh fisheries. Food Policy 26(3):297-313 
Baecke E, Rogiers G, De Cock L, Van Huylenbroeck G (2002) The supply chain and conversion to organic farming in Belgium or the story of the egg and the chicken. Br Food J 104(3/4/ 5): $163-174$

Bahr M, Botschen M, Laberentz H, Naspetti S, Thelen E, Zanoli R (2004) The European consumer and organic food. School of Management and Business, University of Wales Aberystwyth, Aberystwyth

Barnard CS, Nix JJ (1979) Farm planning and control, 2nd edn. CUP, Cambridge, 600 pp

Barrientos S, Dolan C, Tallontire A (2003) A gendered value chain approach to codes of conduct in African horticulture. World Dev 31(9):1511-1526

Becerril J, Abdulai A (2010) The impact of improved maize varieties on poverty in Mexico: a propensity score-matching approach. World Dev 38(7):1024-1035

BER (2012) Bangladesh economic review. Economic Adviser's Wing, Finance Division, Ministry of Finance, Government of the People's Republic of Bangladesh, Dhaka

Berg H (2001) Pesticide use in rice and rice-fish farms in the Mekong Delta, Vietnam. Crop Prot 20 (10):897-905

Berg H (2002) Rice monoculture and integrated rice-fish farming in the Mekong Delta, Vietnam economic and ecological considerations. Ecol Econ 41(1):95-107

Bernard H (2006) Research methods in anthropology: qualitative and quantitative approaches. Alta Mira Press, Oxford

Bolwig S, Ponte S, Du Toit A, Riisgaard L, Halberg N (2010) Integrating poverty and environmental concerns into value-chain analysis: a conceptual framework. Dev Policy Rev 28 (2):173-194

Christensen V, Steenbeek J, Failler P (2011) A combined ecosystem and value chain modeling approach for evaluating societal cost and benefit of fishing. Ecol Model 222(3):857-864

Coche AG (1967) Fish culture in rice fields a world-wide synthesis. Hydrobiologia 30(1):1-44

Coles C, Mitchell J (2011) Gender and agricultural value chains: a review of current knowledge and practice and their policy implications. ESA working paper No 11-05. Agricultural Development Economics Division, Food and Agriculture Organization of the United Nations, Rome

Courtney P, Mayfield L, Tranter R, Jones P, Errington A (2007) Small towns as "sub-poles" in english rural development: investigating rural-urban linkages using sub-regional social accounting matrices. Geoforum 38(6):1219-1232

Dey MM, Prein M (2006) Community-based fish culture in seasonal floodplains. NAGA World Fish Cent Q 29(1-2):21-27

Dey MM, Spielman DJ, Haque ABMM, Rahman MS, Valmonte-Santos R (2013) Change and diversity in smallholder rice-fish systems: recent evidence and policy lessons from Bangladesh. Food Policy 43:108-117

Dillon JL, Hardaker JB (1989) Farm management research for small farmer development, vol 41. Food and Agriculture Organization of the United Nations, Rome

DoF (2010) Fisheries statistical yearbook of Bangladesh. Department of Fisheries, Ministry of Fisheries and Livestock, Dhaka

Dolan C, Humphrey J (2004) Changing governance patterns in the trade in fresh vegetables between Africa and the United Kingdom. Environ Plan A 36(3):491-510

Doss CR (2006) Analyzing technology adoption using microstudies: limitations, challenges, and opportunities for improvement. Agric Econ 34(3):207-219

Dugan P, Dey MM, Sugunan VV (2006) Fisheries and water productivity in tropical river basins: enhancing food security and livelihoods by managing water for fish. Agric Water Manag 80 (1):262-275

Fan S, Pandya-Lorch R (eds) (2012) Reshaping agriculture for nutrition and health. International Food Policy Research Institute, Washington, DC

FAO (2005a) EASYPol. On-line resource materials for policy making. Analytical tools. Module 043. Commodity chain analysis. Constructing the commodity chain, functional analysis and flow charts. Food and Agriculture Organization of the United Nations, Rome. www.fao.org/ docs/up/easypol/330/cca_043EN.pdf. Accessed Nov 2009 
FAO (2005b) EASYPol. On-line resource materials for policy making. Analytical tools. Module 044. Commodity chain analysis. Financial analysis. Food and Agriculture Organization of the United Nations, Rome. www.fao.org/docs/up/easypol/331/CCA_044EN.pdf. Accessed Nov 2009

FAO (2006) Strengthening national food control systems. Guidelines to assess capacity building needs. Food and Agriculture Organization of the United Nations, Rome

Fasse A, Grote U, Winter E (2009) Value chain analysis methodologies in the context of environment and trade research. Discussion paper No 429. School of Economics and Management, Leibniz University, Hannover

Feder G, Just RE, Zilberman D (1985) Adoption of agricultural innovations in developing countries: a survey. Econ Dev Cult Change 33(2):255-298

Fernando CH (1993) Rice field ecology and fish culture: an overview. Hydrobiologia 259 (2):91-113

Finnveden G, Moberg A (2005) Environmental systems analysis tools: an overview. J Cleaner Prod 13(12):1165-1173

Frei M, Becker K (2005) Integrated rice-fish culture: coupled production saves resources. Nat Res Forum 29(2):135-143

Gereffi G (1994) The organization of buyer-driven global commodity chains: how US retailers shape overseas production networks. In: Gereffi G, Korzeniewicz M (eds) Commodity chains and global capitalism. Praeger, Westport, pp 95-123

Gereffi G (1995) Global production systems and third world development. In: Stallings B (ed) Global change, regional response: the new international context of development. Cambridge University Press, Cambridge, pp 100-142

Gereffi G, Humphrey J, Kaplinsky R, Sturgeon T (2001) Globalization, value chains and development. IDS Bull 32(3):1-9

Giap DH, Yi Y, Kwei Lin C (2005) Effects of different fertilization and feeding regimes on the production of integrated farming of rice and prawn Macrobrachium rosenbergii (De Man). Aquacult Res 36(3):292-299

Gibbon P (2000) Back to the basics through delocalisation: the Mauritian garment industry at the end of the twentieth century. Working paper 00.7. Centre for Development Research, Copenhagen

Guptill A, Wilkins JR (2002) Buying into the food system: trends in food retailing in the US and implications for local foods. Agric Hum Values 19(1):39-51

Gurung TB, Wagle SK (2005) Revisiting underlying ecological principles of rice-fish integrated farming for environmental, economical and social benefits. Our Nature 3(1):1-12

Hagedorn K (2008) Particular requirements for institutional analysis in nature-related sectors. Eur Rev Agric Econ 35(3):357-384

Halwart M, Gupta MV (eds) (2004) Culture of fish in rice fields. Food and Agriculture Organization of the United Nations and The WorldFish Center, Rome/Penang

Halwart M, Borlinghaus M, Kaule G (1996) Activity pattern of fish in rice fields. Aquaculture 145 (1):159-170

Haque MM, Little DC, Barman BK, Wahab MA (2010) The adoption process of ricefield-based fish seed production in Northwest Bangladesh: an understanding through quantitative and qualitative investigation. J Agric Educ Ext 16(2):161-177

Hecht JE (2007) National environmental accounting - a practical introduction. Int Rev Environ Res Econ 1:3-66

Holland J (2007) Tools for institutional, political, and social analysis of policy reform, A source book for development practitioners. The World Bank, Washington, DC

Humphrey J, Schmitz H (2001) Governance in global value chains. IDS Bull 32(3):19-30

IFPRI (2010) Research and extension of rice-fish technology in Bangladesh: an expert opinion forum. A Cereal System Initiative for South Asia (CSISA) study on developing and eploying new technologies to smallholders in South Asia: key policies and issues. Forum report. International Food Policy Research Institute, Washington, DC Islam, A. H. M. S., Barman, B. K., \& Murshed-e-Jahan, K. (2015) Adoption and impact of integrated rice-fish farming system in Bangladesh. Aquaculture 447:76-85 
Islam AHMS, Barman BK, Murshed-e-Jahan K (2015) Adoption and impact of integrated rice-fish farming system in Bangladesh. Aquaculture 447:76-85

Kaplinsky R (2000) Globalisation and unequalisation: what can be learned from value chain analysis? J Dev Stud 37(2):117-146

Kaplinsky R, Morris M (2001) A handbook for value chain research, vol 113. International Development Research Centre, Ottawa

Kay RD, William ME, Patricia AD (2008) Farm management, 6th edn. McGraw-Hill Companies, New York

Kim S, Shin E (2002) A longitudinal analysis of globalization and regionalization in international trade: a social network approach. Soc Forces 81(2):445-471

Kledal PR (2006) The Danish organic vegetable chain. Report No 182. Den Kgl. Veterinarog Lantbohojskole, Copenhagen

Kohls RL, Uhl JN (2002) Marketing of agricultural products, 9th edn. Prentice-Hall, Upper Saddle River

Kurttila M, Pesonen M, Kangas J, Kajanus M (2000) Utilizing the analytic hierarchy process (AHP) in SWOT analysis - a hybrid method and its application to a forest-certification case. For Policy Econ 1(1):41-52

Lenzen M (2001) Errors in conventional and input-output-based life-cycle inventories. J Ind Ecol 4(4):127-149

Lightfoot C, van Dam A, Costa-Pierce B (1992) What's happening to rice yields in rice-fish systems? In: dela Cruz CR, Lightfoot C, Costa-Pierce BA, Carangal VR, Bimbao MP (eds) Rice-Fish research and development in Asia, ICLARM conference proceedings 24, Manila, pp $177-183$

Little DC, Surintaraseree P, Innes-Taylor N (1996) Fish culture in rainfed rice fields of northeast Thailand. Aquaculture 140(4):295-321

Macfadyen G, Nasr-Alla AM, Al-Kenawy D, Fathi M, Hebicha H, Diab AM, Hussein SM, AbouZeid RM, El-Naggar G (2012) Value-chain analysis-an assessment methodology to estimate Egyptian aquaculture sector performance. Aquaculture 362-363:18-27

Maertens M, Swinnen JF (2010) Are African high-value horticulture supply chains bearers of gender inequality? In: Workshop on gaps, trends and current research in gender dimensions of agricultural and rural employment: differentiated pathways out of poverty, vol 31, Rome

Minten B, Murshid KAS, Reardon T (2011) The quiet revolution in agrifood value chains in Asia: the case of increasing quality in rice markets in Bangladesh, vol 1141. International Food Policy Research Institute, Washington, DC

Minten B, Murshid KAS, Reardon T (2013) Food quality changes and implications: evidence from the rice value chain of Bangladesh. World Dev 42:100-113

Nabi R (2008) Constraints to the adoption of rice-fish farming by smallholders in Bangladesh: a farming systems analysis. Aquac Econ Manag 12(2):145-153

Nhan DK, Phong LT, Verdegem MJ, Duong LT, Bosma RH, Little DC (2007) Integrated freshwater aquaculture, crop and livestock production in the Mekong delta, Vietnam: determinants and the role of the pond. Agric Syst 94(2):445-458

Nix J (2000) Farm management pocketbook, 31st edn. Wye College, London, p 244

Noltze M, Schwarze S, Qaim M (2012) Understanding the adoption of system technologies in smallholder agriculture: the system of rice intensification (SRI) in Timor Leste. Agric Syst 108:64-73

Ondersteijn CJ, Wijnands JH, Huirne RB, Kooten OV (eds) (2006) Quantifying the agri-food supply chain, vol 15 . Springer, Wageningen

Pacini C, Giesen G, Wossink A, Omodei-Zorini L, Huirne R (2004) The EU's Agenda 2000 reform and the sustainability of organic farming in Tuscany: ecological-economic modelling at field and farm level. Agric Syst 80(2):171-197

Pant J, Barman BK, Murshed-E-Jahan K, Belton B, Beveridge M (2014) Can aquaculture benefit the extreme poor? A case study of landless and socially marginalized Adivasi (ethnic) communities in Bangladesh. Aquaculture 418:1-10 
Rahman S (2013) Formalin-never ending woe. New Age. The Bangladesh Chronicle, 15 Jan 2013

Reardon T, Chen K, Minten B, Adriano L (2012) The quiet revolution in staple food value chains: enter the dragon, the elephant, and the tiger. Asian Development Bank International Food Policy Research Institute, Manila/Washington, DC

Rebitzer G, Ekvall T, Frischknecht R, Hunkeler D, Norris G, Rydberg T, Schmid WP, Suh S, Weidema BP, Pennington DW (2004) Life cycle assessment: part 1: framework, goal and scope definition, inventory analysis, and applications. Environ Int 30(5):701-720

Riisgaard L, Bolwig S, Ponte S, Du Toit A, Halberg N, Matose F (2010) Integrating poverty and environmental concerns into value-chain analysis: a strategic framework and practical guide. Dev Policy Rev 28(2):195-216

Roos N, Islam MM, Thilsted SH (2003) Small indigenous fish species in Bangladesh: contribution to vitamin A, calcium and iron intakes. J Nutr 133(11):4021-4026

Roos N, Wahab MA, Chamnan C, Thilsted SH (2007a) The role of fish in food-based strategies to combat vitamin A and mineral deficiencies in developing countries. J Nutr 137(4):1106-1109

Roos N, Wahab M, Hossain MAR, Thilsted SH (2007b) Linking human nutrition and fisheries: incorporating micronutrient-dense, small indigenous fish species in carp polyculture production in Bangladesh. Food Nutr Bull 28(Supplement 2):280-293

Roth S, Hyde J (2002) Partial budgeting for agricultural businesses. Pennsylvania State University, unpublished manual. http://pubs.cas.psu.edu/freepubs/pdfs/ua366.pdf. Accessed 10 Feb 2014

Rothuis AJ, Nhan DK, Richter CJJ, Ollevier F (1998a) Rice with fish culture in the semi-deep waters of the Mekong Delta, Vietnam: interaction of rice culture and fish husbandry management on fish production. Aquacult Res 29(1):59-66

Rothuis AJ, Nhan DK, Richter CJ, Ollevier F (1998b) Rice with fish culture in the semi-deep waters of the Mekong Delta, Vietnam: a socio-economical survey. Aquacult Res 29(1):47-57

Rothuis AJ, Vromant N, Xuan VT, Richter CJJ, Ollevier F (1999) The effect of rice seeding rate on rice and fish production, and weed abundance in direct-seeded rice-fish culture. Aquaculture 172(3):255-274

Ruel MT, Alderman H (2013) Nutrition-sensitive interventions and programmes: how can they help to accelerate progress in improving maternal and child nutrition? Lancet 382 (9891):536-551

Sarder R (2007) FAO fisheries technical paper, no 501. In: Bondad-Reantaso MG (ed) Freshwater fish seed resources in Bangladesh: assessment of freshwater fish seed resources for sustainable aquaculture. Food and Agriculture Organization of the United Nations, Rome, pp 105-128

Shang YC (1986) Research on aquaculture economics: a review. Aquac Eng 5(2):103-108

Sturgeon TJ (2001) How do we define value chains and production networks? IDS Bull 32(3):9-18

Thilsted SH, Roos N, Hassan N (1997) The role of small indigenous fish species in food and nutrition security in Bangladesh, Naga. ICLARM Q 20(3-4):82-84

Trifković N (2014) Governance strategies and welfare effects: vertical integration and contracts in the catfish sector in Vietnam. J Dev Stud (ahead-of-print), 50(7):1-13

Uddin R, Wahid MI, Jasmeen T, Huda NH, Sutradhar KB (2011) Detection of formalin in fish samples collected from Dhaka city, Bangladesh. Stamford J Pharm Sci 4(1):49-52

Veliu A, Gessese N, Ragasa C, Okali C (2009) Gender analysis of aquaculture value chain in Northeast Vietnam and Nigeria. World Bank agriculture and rural development discussion paper 44. The World Bank, Washington, DC

Walters D, Lancaster G (2000) Implementing value strategy through the value chain. Manag Decis 38(3):160-178

William JG, Hella JP, Mwatawala MW (2012) Ex-ante economic impact assessment of green manure technology in maize production systems in Tanzania. Res Hum Soc Sci 2(9):47-58

Williamson OE (1985) The economic institutions of capitalism: firms, markets, relational contracting. Collier Maximilian Publisher, London

Wood A (2001) Value chains: an economist's perspective. IDS Bull 32(3):41-45

World Bank (2012) Bangladesh: annual economic update. Poverty reduction and economic management, South Asia region. The World Bank, Washington, DC 